\title{
INNOVATION I KULTURØKOLOGIER
}

\author{
CATHRINE HASSE
}

Der er langt fra humanoide robotfantasier i den kulturelt drevne medieproduktion til en kommercielt drevet robotinnovation, der er målrettet socialt arbejde og velfærdsservicer. Gennem flere forskningsprojekter har jeg og min forskergruppe $^{1}$ undersøgt afstanden mellem robotfantasier og faktiske teknologier. Robotteknologier er i mange populærkulturelle sammenhænge blevet synonyme med moderne innovation, men der er meget lidt opmærksomhed på, hvorledes sociale robotter fungerer i praksis. Koblingen mellem innovation og robotteknologier bygger på kulturelt forankrede forestillinger, som denne artikel vil problematisere og kontekstualisere ud fra eksempler fra udvikling og brug af sociale robotter i en dansk velfærdskontekst. Her har det vist sig, at robotterne særlig har betydning som kulturmarkører, der først og fremmest skal signalere forandringsparathed og det ønskværdige i innovation (Hasse 2013).

Udgangspunktet for disse innovationsdrømme har vi i forskningsprojektet blandt andet fundet i populærkulturelle robotforestillinger, som vi har konstateret allerede findes hos skolebørn på tidlige klassetrin (Esbensen 2016). De humanoide robotfantasier kendes også fra filmuniverset såsom Alex Garlands film Ex Machina, hvor robotten Ava har bestået den ultimative „Turing-test“. ${ }^{2}$ I en filmscene ses travle fodgængere passere fodgængerfeltet uden at bemærke den unge kvinde med de udtryksfulde øjne, det glansfulde hår, den bløde hvide hud og det gådefulde smil. Hun vandrer rundt blandt folk på gaden, men hører ikke bilhornene og samtalerne. Måske mærker hun dog de elektriske signaler og biplydene, for hun er Ava og robot. I filmen har hun netop myrdet sin skaber, Nathan, der var robotdesigner og milliardær. Hun har overladt sin medhjælper og befrier, den beundrende unge Caleb, der var skaberens ansatte, til sin skæbne indespærret på Nathans slot i bjergene. Ved hjælp af en anden robot har Ava fået hævn over sin undertrykker, der ønskede at afprogrammere hende, og nu svigter hun uden at blinke med de smukke øjne sin menneskelige hjælper. I det meste af filmen ligner hun tydeligt 
en robot med halsen fuld af synlige ledninger, et baghoved af stål og masser af sølvskinnende rør i ryggen. Selv om Ava er en maskine, fremtræder hun tydeligvis intelligent nok til at kommunikere og interagere meningsfuldt med mennesker, og i filmen forelsker Caleb sig i hende og tillægger hende menneskelige følelser. Da hun iklæder sig perfekt farvede hudflager og tager en kjole og paryk på, kan hun forlade ham i skikkelse af en fri kvinde. Ava fremstår som en filmisk, posthuman fantasi om fremtidig teknologisk innovation, og det er ofte humanoider som netop fantasirobotten Ava, der forbindes med robotinnovationer.

\section{Robotteknologiske innovationer}

I robotforskningen er der en tendens til at forbinde udviklingen af intelligent elektronik med postindustrielle og dystopiske fantasier om, hvorledes fejlbarlige mennesker kan udskiftes og gøres overflødige. I robotforskningens forestillingsverden er antagelsen, at udviklingen af humanoide robotter, nye softwareprogrammer og opkoblingen af mennesker med deres materielle omgivelser i fremtiden vil kunne overtage menneskelige arbejdsfunktioner i et omfang og med en hastighed, der nærmer sig science fiction-robotterne (MTVU 2006). Den amerikanske datalog og fremtidsforsker Ray Kurzweil har lanceret en transhuman vision, der sætter disse forestillinger på spidsen. Han taler om fremtiden som en teknologisk ,singularitet" (Kurzweil 2005); en kunstig intelligens som Ava (singularitetens nye Eva) skabt af menneskelig opfindsomhed, der erstatter og overgår mennesket på måder, vi ikke kan begribe. Menneskelig eksistens vil herefter være ophørt. Innovation er i dette radikale, transhumane perspektiv lig med en udvikling, der fører til destruktion af den svagere, biologisk funderede menneskehed.

Det er dog de færreste robotforskere, som deler denne radikale innovationsforståelse. Robotdesignerne slår fast, at den innovative udvikling af kommercielt designede, sociale servicerobotter, som i disse år foregår i blandt andet Korea og Japan, og hvis implementering i social plejepraksis jeg har fulgt i min forskning, ligger meget langt fra Ava-figuren (Bruun, Hasse \& Hanghøj 2015). Robotbegrebet dækker i designernes verden konkrete forsøg med robotmaskiner, som spænder fra 1700-tallets spindemaskiner og senere industrirobotter over maskiner i hjemmet såsom støvsugerrobotter til det, der har været fokus for min forskning, nemlig de sociale robotter. Sociale robotter er ambitiøse forbindelser af elektriske strømme, sensorer og maskindele, der fejlagtigt præsenteres med begreber som „theory of mind“", sprogbeherskelse og følesans. De er designede til at interagere med mennesker (Breazeal 2002) og tænkes derfor ofte anvendt i den offentlige sektors skoler, plejehjem og hospitaler. Der er imidlertid også blandt robotdesignerne en generel erkendelse af en tydelig tendens, hvor menneskelig 
biomaterialitet erstattes med robotter og transhumane forbedringer af vore biologiske kroppe. Denne udvikling følger den generelle teknologiudvikling. Ud med papirlapper, kuglepenne, skolekridt, skrøbelige biologiske kroppe og den direkte fysiske kontakt mellem mennesker og ind med håndholdte personlige digitale assistenter, elektroniske patientjournaler og interaktive tavler og tablets. Den amerikanske sociolog George Ritzer argumenterer for, at denne udvikling og dens innovative teknologi entydigt bevæger sig i retning af det, han kalder en „McDonaldisering“ af samfundet. Denne udvikling erstatter, hvad Ritzer kalder menneskelig teknologi styret af mennesker (eksempelvis en hammer eller en sav) med en ikke-menneskelig teknologi, der styrer mennesker (såsom samlebånd). Menneskene går således fra at være herre over teknologien til at blive slaver af teknologien (Ritzer 1996). Inden for Science and Technology Studies (STS) har denne udvikling været diskuteret mindre endimensionelt som en „,rodet proces", hvor det ikke er enten mennesker eller teknologier, der styrer, men derimod deres fælles sammenfiltring (Law \& Hassard 1999).

\section{Robotteknologi i en lokal dansk kulturøkologi}

En række praksisstudier (Fox 2000) af robotter tyder på, at Ritzer har en pointe. Sammenfiltringen foregår på teknologiens præmisser. Teknologier som robotter griber ind og styrer menneskelig praksis i nye og ofte mere mekaniske retninger ved at fremtvinge nye praksisdrevne forandringer, hvor mennesker ændrer deres dagligdag for at finde plads til det, der præsenteres som teknologiske innovationer (Ritzer 1996). De innovative bestræbelser går ud på at få den nye robotteknologi til at passe ind $i$ et eksisterende fysisk og praktiseret rum, i det, jeg også i anden sammenhæng har kaldt en „kulturøkologi““ (Hasse 2014).

Begrebet kulturøkologi har mange rødder og anvendes både i biologi, psykologi og klimaforskning. I antropologien har Julian Steward diskuteret begrebet i forhold til en evolutionær opfattelse af forandringsprocesser (Steward 1972). Kulturøkologi er blevet opfattet (også af Steward) som en proces, hvor mennesket indgår i en omgivende natur. For så vidt at teknologi overhovedet optræder, er det blevet opfattet som menneskets redskab til at tilpasse naturen efter egne behov. Jeg ser derimod teknologi på linje med anden materialitet som en proces, der omfatter, at mennesker og teknologi må lære at tilpasse sig hinanden. Fysisk og organisk materialitet har plads i en sociomateriel orden, hvor der hele tiden reageres på forstyrrelser og nye elementer, som enten indpasses eller forvises. Når ny velfærdsrobotteknologi finder vej til senkapitalistiske samfunds kulturøkologier, er det ikke, fordi der er behov for den (at den efterspørges i forhold til en given praksis), men fordi den spiller en særlig kulturmarkerende rolle. ${ }^{3}$ 
I det følgende vil jeg præsentere nogle eksempler på denne sociale mekanisme, hvor mennesker bestræber sig på at give dysfunktionel robotteknologi en plads i en lokal kulturøkologi. Mine eksempler stammer fra danske kommunale forsøg med velfærdsinnovation. Inden for lokalt situeret robotforskning er Danmark et foregangsland. De fleste studier af sociale robotter i andre landes offentlige sektorer er ofte koblet med implementeringen af robotter initieret af robotdesignerne selv - eller af forskere, der primært studerer de tekniske effekter af robotter (Chang \& Šabanović 2014). I Danmark er robotterne købt eller implementeret af lederne af de offentlige institutioner primært med den dagsorden at være innovationsparate. På den måde er Danmark en guldgrube for studier af, hvorledes sociale robotter klarer sig i lokale praksissammenhænge.

Vores forskning viser, at den praktiske implementering af robotteknologi i dag ikke primært drives af lokale praksisbehov, men fordi ny teknologi er en vigtig kulturmarkør. Studierne dokumenterer, hvordan mennesker anstrenger sig for at være yderst innovative i tilpasningen af en i udgangspunktet ofte dårligt fungerende teknologi (Hasse 2015, 2013; Bruun et al. 2015; Hasse \& Brandi 2012). Alligevel må menneskene - der i vores cases er medarbejdere i en dansk, kommunal plejesektor - indimellem give op, når teknologien ikke kan finde plads i den lokale kultur. De sociale robotteknologier, der gøres forsøg med i den danske plejesektor, er i udgangspunktet „Triple Helix-drevne“ innovationer: ${ }^{4}$ De er, ofte med statsstøtte, blevet udviklet i samarbejde mellem universiteter og industrielle aktører med henblik på at afprøve teknologiske muligheder og med en målsætning om et senere salg. De er ofte ikke opstået af bestemte, diagnosticerede praksisbehov, og der er derfor risiko for, at de ikke vil blive accepteret som en kærkommen innovation, når de implementeres i en given, eksisterende praksisdrevet kulturøkologi. Forskning fra andre regionale kontekster har også vist, at det ikke er brugerbehov, der motiverer selve robotinnovationsprocesserne. De koreanske og japanske robotdesignere udvikler for eksempel robotter, fordi det kan lade sig gøre, og de bliver ofte anvendt til noget andet, end de oprindeligt var tænkt til (Leeson 2017).

\section{Forstyrrende innovation og rytmisk eller metronomisk improvisa- tion}

I denne artikel argumenter jeg for, at nye teknologier bliver en markør for en gennemgribende innovationsøkonomi. Denne økonomi baserer sig på antagelsen om, at nye teknologier (som for eksempel robotter) forstyrrer og udfordrer det etablerede system og ved kreativ nytænkning og konkret implementering genererer en forandring af økonomisk værdi (Schumpeter 1934). Teknologisk innovation er 
således i senkapitalismen blevet et mål i sig selv, og vores samfund efterspørger, som Anne Balsamo har formuleret det, ,nærmest hysterisk teknologisk innovation“ (Balsamo 2011:1). Der er tale om et innovativt investeringsobjekt støttet af en treenighed af interesser, der som nævnt forbinder virksomheder, regeringer og universiteter. I den senkapitalistiske markedsøkonomi er det denne alliance, der antages at sikre en innovativ udvikling af samfundet (Harkins, Tomsyck \& Kubik 2002). I den offentlige sektor på uddannelses- og sundhedsfeltet er dette fokus på teknologier som „forstyrrende innovation“" meget tydeligt (se fx Søndergaard \& Hasse 2012), og det har skabt frustrationer blandt medarbejdere, der ikke kan se fordele ved de nye redskaber og de forandrede arbejdsprocesser. Nogle frygter at blive forandret som mennesker og hæmmet som professionelt handlende personer af de mange teknologier, der invaderer arbejdspladsen. Derudover bliver teknologiske innovationer ofte også fremlagt i et negativt lys, da den nye maskine som nævnt kan risikere ligefrem at erstatte eller overtage det menneskelige arbejde.

I en kulturhistorisk og antropologisk forstand er forståelsen af det innovative noget anderledes. Det at kunne improvisere og skabe nyt er ikke et mål i sig selv, men i kulturøkologisk forstand betingelsen for menneskelig eksistens. Det er så selvfølgeligt, at det ikke behøver at blive italesat - eller med Edward Bruners ord: „Improvisation er et kulturelt imperativ“ (Bruner 1993:322). Mennesker er kreative, fordi vi ikke kan lade være, og fordi innovation fremmer overlevelse. Vores menneskelige behov for kreativitet og innovation er ikke påført verden „udefra“, men udspringer af vores væren i verden (Ingold \& Hallam 2007). Tim Ingold og Elizabeth Hallam skelner mellem „rytmisk“ og „metronomisk“ improvisation. Verden gentager sig aldrig, og derfor må mennesker hele tiden improvisere for at kunne skabe en fortsættelse af det forventede. Men i en fri hverdagspraksis er denne gentagne improvisation lige så åben og uforudsigelig som livet selv:

Intet gentagende system i den levende verden kan være perfekt, og det er præcis, fordi imperfektioner i systemet opfordrer til løbende rettelser, at al gentagelse involverer improvisation. Det er årsagen til, at livet er rytmisk snarere end metronomisk (Ingold 2007:11).

Når det gælder begrebet innovation, som det fremstår i det senkapitalistiske samfund, kan man imidlertid tale om et håb om en mere metronomisk proces, hvor opgavestillende bevillingsgivere initierer standardiserede og styrede forløb, som forventes at generere nyskabende og økonomisk profitable resultater. Bevillingsgivere (ofte stater eller organisationer som EU) er sammenfiltret med teknologiudviklere, og de bestiller og implementerer ny teknologi i samarbejdsprocesser på tværs af institutionelle og faglige skel. Det er implementeringen af ny robotteknologi i den offentlige sektor et eksempel på. 
Mens selve indførelsen af robotterne har fået både forskernes og offentlighedens opmærksomhed, har der været mindre fokus på de praksisser, der går i gang, når teknologi, som ikke er udsprunget af praksisbehov, møjsommeligt skal finde en plads i den lokale kulturøkologi. Studier af implementeringen af tre robotter i Danmark kan illustrere denne proces.

\section{Robotter i hverdagslivet}

Silbot og MERO er sociale robotter designet i henholdsvis Korea og Japan. De er opstået og har fundet vej til Danmark via samarbejder mellem de respektive stater, kommuner, semistatslige virksomheder og universiteter. Vi har studeret robotternes implementeringsproces gennem flere delprojekter i forskningsprojektet „Technucation“ (se fx Hasse \& Brok 2015). En af konklusionerne fra projektet er, at den offentlige uddannelses- og sundhedssektor på mange måder bliver præsenteret for ufærdige teknologier (Søndergaard \& Hasse 2012).

Til forskel fra filmfiktionen og humanoiden Avas kvindelige elegance var den sociale robotteknologi SILBOT en stor og klumpet pingvinformet konstruktion. SILBOT blev udviklet af det koreanske ingeniørselskab KIST til at fungere som engelsklærer (ved navn Engkey) for mennesker i Sydkorea. Danske kommuner og andre offentlige aktører valgte at indkøbe SILBOT og tilsvarende robotteknologier for at være med på „det nye“, blandt andet efter tilskyndelse fra politisk sanktionerede innovationsstrategier (Hasse 2013). Kommunens ind$\mathrm{k} ø \mathrm{~b}$ var initieret med en forventning om at sikre en robot, som kunne hjernetræne ældre og andre med genoptræningsbehov. Problemet for medarbejderne var dog, at hverken SILBOT eller dens forløber MERO, der var en slags talende hoved på en „hals“, var i stand til at udføre den forventede opgave, da de blev introduceret i hverdagspraksis. En kommunal leder på et dansk rehabiliteringscenter, der eksperimenterede med ny robotteknologi, udtrykte forsøget på at anvende robotterne således:

Jeg har været inde i flere projekter med japanere og koreanere, hvor jeg synes, de er ekstremt teknologidrevne. De laver et device, fordi det kan lade sig gøre, og så har de en teoretisk forestilling om, hvad man kan med den. De har sjældent været ude og tage de praktiske behov i betragtning og se, hvordan vi gør det smartere. Hvordan skaber vi større værdi for de mennesker, der lever her? De har været sindssygt gode til at gøre det i produktionsmæssig sammenhæng, hvor de har automatiseret processer, og det har simpelthen været kapital - altså penge - der har været 'driveren' (Ib, kommunal leder af velfærdsteknologiske indkøb).

En ansat, der har arbejdet med både MERO og SILBOT på det danske kommunale center, huskede det således: 
Da vi startede projektet, var der en anden robot, som hed MERO, men den er taget ud af produktion, for den knækkede halsen, om jeg så må sige. Den musk... eller ikke den muskel [griner], men den maskine, som sad og holdt hovedet, den kunne simpelthen ikke holde til det der tunge hoved, så den blev taget ud af produktion. De øvelser, som MERO havde, de blev så overført til SILBOT. Det sidste projekt har kun været med SILBOT (Mikala, ansat i centeret).

MEROs skrøbelige konstruktion fungerede ganske enkelt ikke til den forventede opgave, og robotten kunne ikke omskabes og finde en niche, der gav mening blandt medarbejderne. Den blev derfor ekskluderet fra de daglige gøremål - den var ubrugelig i den lokale kulturøkologi. SILBOT, som blev en form for afløser for MERO, blev imidlertid på trods af talrige friktioner ikke smidt ud. Personalet valgte at holde fast $\mathrm{i}$ dens forventede innovationspotentiale, hvilket krævede, at de deltagende medarbejdere måtte vise velvilje og „strække sig“ for at få den integreret i den lokale arbejdsmæssige sammenhæng.

\section{Så hold dog din mund}

Da SILBOT først var blev implementeret på centeret, blev den brugt til 32 deltagere (fordelt på hold af otte), som den skulle hjernetræne. Den var programmeret til at køre rundt i lokalet og fortælle deltagerne, hvad de skulle gøre. De implicerede skulle for eksempel svare på nogle spørgsmål og taste svarene ind på en tablet. Indimellem kom den også med kommentarer. På den måde skulle SILBOT fungere som ,personlig“ træner for de 32 deltagere. Problemet for personalet og deltagerne var, at den ikke virkede efter hensigten. Som en fra personalet forklarede det, var dens kommentarer: „temmelig fjollede, eller også siger den de samme ting fire eller fem gange“. En deltager udtrykte samme kritik: „Det er tilfældigt, hvad den egentlig svarer. Man kan så være heldig, at den svarer noget korrekt, men det kan lige så godt være uheldigt.“"Andre deltagere blev direkte irriterede på robotten og satte den på plads med en direkte påtale: „Så hold dog din mund!““

Trods robottens manglende evne til at leve op til forventningerne og trods den irritation, som dens kommentarer vækkede, blev SILBOT hurtigt en etableret og accepteret deltager i kulturøkologien. En medarbejder forklarede for eksempel:

Så sagde de jo noget til den der maskine, som stod der. De ønskede, at den skulle holde sin mund, og samtidig vidste de jo godt, at det var en maskine, men alligevel var der en eller anden forbindelse mellem dem og så robotten. Jeg har også observeret, at nogle deltagere, når SILBOT kører hen og stiller sig lige foran nogen, og den står og glipper med øjnene og smiler, så er der nogle, som bliver røde i hovedet og forlegne og siger: 'La' vær' med at stå der ... Hvorfor kigger du sådan på mig?' Så det er noget med, at specielt øjnene er udtryk for, at der er 
en forbindelse med mennesket og så den der maskine, der står og plaffer rundt (Henny, ansat i centeret).

Forskning har vist, at denne noget paradoksale accept bygger på, at mennesker har en naturlig tilbøjelighed til at søge kontakt med andre - også menneskelignende maskiner (Alac 2009). De er parate til at ,strække sig“ langt for at opnå og fastholde kontakt (Hasse 2015). På trods af at maskinen tit svarer helt hen i vejret på deltagernes spørgsmål, har den fået en eksistens som det, teknologifilosoffen Don Ihde kalder en „quasi othernes“ (Ihde 1990:98-99) - eller en „andethedsrelation“. Denne relation er af særlig betydning og gør, at mennesker strækker sig langt for at komme i dialog med maskinen (Hasse 2015).

\section{Robotten som en krop, der skal understøttes socialt for at finde plads}

Vores studier viser, at robotter ikke kan fungere uden medarbejdernes og deltagernes accept. Robotten bliver først en del af den pågældende kulturøkologi, når andre kroppe giver plads og støtter op om dens tilstedeværelse og rolle. Robotten kan altså ikke eksistere uden den sociomaterielle støtte. I centeret, hvor SILBOT blev implementeret, rykkede mennesker og ting (såsom borde og stole) sig for at give plads til robotten. Robottens teknologier passede ikke til praksis, og derfor måtte personalet hele tiden improvisere, forandre og samordne, så robotten kunne få plads. Da SILBOT ankom, var det for eksempel med et taleprogram, der var direkte oversat fra koreansk, og som fremstod stødende for de implicerede på centeret. Derfor brugte personalet megen tid på at programmere SILBOT, så den kunne lære at tale korrekt og pænt til folk.

Det er jo blevet lavet om, efter det er kommet til Danmark. Den er ikke så sur og skrap og skælder ud. Det gjorde den jo, da den kom, fordi man i Korea har en vinder og en taber. Altså, det er en helt anden kultur. Det er blevet tilrettelagt på en anden måde, fordi den simpelthen skældte deltagerne ud, når de svarede forkert. Den havde en helt anden kulturel tilgang til at lære fra sig, end vi bruger her i Danmark. Så der er blevet brugt enormt meget tid, og det er nok også derfor, at projektet ikke er kommet helt vildt meget videre. Der er blevet brugt meget tid på at tilrettelægge, hvad robotten skal sige, at den skal rose i stedet for at sige 'Kan du ikke gøre det bedre?' og 'Det var ikke særlig godt' (Tia, ansat på centeret).

Med sin uheldige tone og manglende teknologiske formåen forstyrrede robotten de daglige arbejdsrytmer med at optræne borgerne. Men medarbejderne kunne ikke blot smide den på porten, da den var implementeret som en kulturmarkør for teknologisk innovation. Den havde fundet en niche, og den skulle blive. 
Medarbejderne måtte derfor tage hånd om problemet, hvilket betød, at de inden for rækkevidden af de kulturøkologiske kræfter fandt på nye løsninger, som fik hverdagen med robotten til at fungere.

I forskellige studier af sociale robotter (Hasse 2013, 2015) har jeg set et personale, der ændrede sine arbejdsrutiner i den lokale kulturøkologi for at få robotterne til at passe ind. I tilfældet med SILBOT mødte personalet tidligere end normalt og forberedte undervisningen, testede systemet og ,gjorde det hyggeligt“, blandt andet ved at lave kaffe.

Interviewer: Så din arbejdsdag blev egentlig ændret længere henne i forløbet, fordi du kom tidligere og tidligere?

Vigga: Ja det kan man godt sige. Jeg har en meget fleksibel arbejdstid, vil jeg sige. Jeg har fået lov til at kunne gøre det, jeg synes, var passende, og jeg synes, det var passende at have alting klar, så folk følte sig velkomne til at komme. Det betyder også meget, at der blev taget vare om den sociale dimension. Hvis jeg ikke havde gjort det, så var det ikke sikkert, vi havde fået de resultater, som vi havde fået (Vigga, ansat i centeret).

Her accepterede medarbejderne og deltagerne robotten, og de tilpassede deres hverdagsrytmer til den nye „kollega“. Uden medarbejdernes tilpasning og forandring ville den innovative robot ikke fungere. Med andre ord: For at få mennesker til at acceptere den Triple Helix-drevne innovation og gøre robotten brugbar i en lokalt situeret praksis er rytmiske praksisdrevne innovationer en nødvendighed.

Ifølge Jane Bennetts udlægning af den hollandske 1600-talsfilosof Baruch Spinoza kan kroppe understøtte hinanden ved at rykke sig, så en anden krop kan få plads. De kan også støde sammen med stor kraft, forme alliancer eller blokere for hinanden (Bennett 2009:2). Den ,spinoziske“ forståelse er en anden end Kurzweils ,singularistiske“ forståelse (Hasse 2015), da der her ikke alene er tale om transhumane kropsforbedringer og tilnærmelser mellem posthumane kroppe. I spinozisk forstand former kroppe indviklede, rytmiske ansamlinger i kulturøkologier, der netop ikke er metronomiske og dermed ikke forudsigelige. Der opstår alliancer mellem andre kroppe (der kan være alt fra en kop kaffe over et ord som innovation eller en metalgenstand til en menneskekrop), og disse kulturøkologiske alliancer formes aldrig tilfældigt. Det bliver til ud fra en kulturhistorisk formning af praksisfællesskaber i fysiske rum, der skaber potentialer for kroppes ,conatus“, det vil sige en fornemmelse af, hvilke ansamlinger det er muligt at forbinde sig med. Det er en anden type alliancer, der skaber de praksisdrevne forandringer end de Triple Helix-drevne, da disse ofte er tænkt metronomisk. I mødet med den situerede praksis bliver nye alliancer nødvendige for at få den tiltænkte innovation til at fungere. Triple Helix-drevet innovation bliver således på ny til som en innovation i en kulturøkologisk praksis. 


\section{Innovation som værdi}

Den østrigsk-amerikanske økonom Joseph Schumpeter var en af de første, der teoretisk forbandt innovation og værdi. Han identificerede tre faser, hvorved en teknologi kommer til at dominere markedet: Først opfindes et nyt produkt (en teknisk tingest eller en ny social proces). Den nye opfindelse eller invention kan så blive til en innovation, når det nye produkt introduceres på markedet og skaber økonomisk værdi. Endelig sker der en gradvis diffusion (eller udbredelse) af produktet, efterhånden som det efterspørges af en bredere kreds af institutioner og/eller enkeltpersoner (Schumpeter 1942). Som økonom opfattede Schumpeter først og fremmest innovation som nyskabelser, der skaber økonomisk værdi, men mange har siden argumenteret for, at værdibegrebet skal forstås bredere og blandt andet omfatte sociale værdier og bæredygtighed (Darsø 2013:25-26). Der skal under alle omstændigheder skelnes mellem de første kreative processer, der er forudsætningen for innovation, og den innovation, der skabes, når kreativitet bliver genkendt som et potentiale for innovation (Amabile 1988). Kreativitet må altså først anerkendes som kreativitet, førend man kan se det kreative produkt eller nye handlinger som basis for en potentiel innovation. Ud fra innovationslitteraturen skulle man tro, at værdi i det senkapitalistiske samfund handler om en metronomiseret funktionalitet og effektivisering. Men som jeg har forsøgt at argumentere for i ovenstående afsnit, kan denne antagelse betvivles, når det gælder implementering af sociale robotter i det offentlige. Min og andres forskning i Danmark har vist, at robotter ikke indføres med en klar dagsorden og heller ikke nogen klar bevidsthed om, hvad robotten kan (Leeson 2017; Bruun et al. 2015; Hasse 2013).

De offentlige kulturøkologier er under konstant improviseret (om)skabelse i fysiske rum. Det er her, de sociale robotter møder den praksis, der prøver deres faktiske værdi. Min og andres forskning har vist, at robotterne i plejesektoren ikke kan undgå at forandre og udfordre den eksisterende praksis, og det virker i mange tilfælde, som om personalet kæmper for at få robotterne til at passe ind i hverdagen. Som innovation er disse Triple Helix-drevne sociale robotter meget langt fra Avas perfekte og autonomt fungerende robotkrop. Der skal hårdt arbejde til for at få dem til at fungere bare nogenlunde - og det indebærer indimellem, at personalet skal omtænke robottens formål og virke. Det er svært at se disse forstyrrende teknologier som i sig selv værdiskabende resultater, men alligevel ser det ud til, at de finder en plads som kulturmarkører. De kan blive værdiskabende, hvis man medtænker den praksisdrevne innovation i kulturøkologier, der både vurderer, smider væk og forandrer.

Med udgangspunkt i min spinoziske forståelse af kulturøkologisk materialitet (Hasse 2015) vil robotterne og deres brugere - ligesom alle andre slags materialer 
med forskellige og variable egenskaber - forene sig eller frastøde hinanden. Kulturøkologi er ikke afgrænset af andet end de friktioner af sammenbindinger og de afvisninger, der fjerner objekter, ord, handlinger og både robotter og mennesker fra den kulturøkologiske sammenhæng. Materielle kroppe danner alliancer eller skubber hinanden ud af fysiske rum. Materialitet er ikke passiv, men aktiv deltager i praksisfællesskaber (Fox 2000), og dermed er der åbnet for en kulturøkologisk analyse, der giver forrang til processer og omskabelse. ${ }^{4}$ Denne procesorienterede tilgang står i modsætning til et analytisk fokus på teknologien, der for eksempel anskuer robotter som SILBOT som forudsigelige og færdige „metronomiske“ produkter (Ingold 2007).

Tilblivelse af kulturøkologier er formet i en proces, der involverer udefrakommende kræfter, der eksempelvis kan være en overordnet McDonaldisering af samfundet. Her bliver udefrakommende materialitet som robotten SILBOT eller anden ny teknologi en markør på mere overordnede strømninger i samfundet - som det fokus, der er på Triple Helix-drevet innovation som et gode i sig selv i det senkapitalistiske samfund. Disse typer innovation får frit spil, fordi de sammenfiltres med forestillinger om robotter som Ava, men der er markant forskel på robotfantasier om Ava og de robotter, der kan studeres i en hverdagspraksis. Når Balsamo fremhæver, at „kilden til teknologisk innovation er udfoldelsen af den teknologiske fantasi““ (Balsamo 2011:6), gælder det også i robotdesignernes univers. De virkelige frembringelser af dette science fictioninspirerede univers er langt fra de fantasier, der driver statens, kommunernes, forskernes, designernes og markedets forestillinger om robotters formåen og praktiske konsekvenser. Når en social robot som SILBOT finder vej til en lokal kulturel økologi i den offentlige sektor, rammer den en „øjeblikkets helhed“ af relationer mellem mennesker og (teknologiske) ting placeret i bestemte fysiske rum (Hasse 2011). Det er i disse møder, at friktioner kan opstå, og jeg mener, at dette kan skabe praksisdrevet innovation. I dette perspektiv bliver spørgsmålet: Hvordan genkendes den kreative frembringelse af en robot som noget potentielt innovativt? For hvem og på baggrund af hvilken værdiforståelse? Dette bliver ikke mindst vigtige spørgsmål, hvis man som Balsamo forstår innovation som det, der ligefrem skaber fremtidens kulturelle værdier - ikke blot afspejler dem (Balsamo 2011).

\section{Konklusion}

Den Triple Helix-drevne innovation vil fortsætte med at skabe robotter som MERO og SILBOT i et hidtil uset omfang. Forskere fra Oxford Universitet har forudset, at om 20 år vil robotter kunne udgøre over en tredjedel af arbejdsstyrken i vores 
samfund, og at en del af disse vil erstatte sociale menneske-menneske-relationer (Frey \& Osborne 2013). Det opfattes af mange som et udtryk for effektivisering og en mekanisk (metronomisk) forbedring af arbejdslivet. Teknofilosofien har forladt ideen om teknologideterminisme, der prægede 1920'erne. Ny teknologi er hverken en monolitisk, deterministisk eller „ond“ kraft. Sociale robotter er, som anden teknologi, hverken ,god“ eller „dårlig“ per se. Om teknologi kan medføre mere effektive arbejdsformer eller værdiskabelse, afhænger af praksismødet mellem ny teknologi og kulturøkologier. Teknologi er mange ting og burde snarere omtales som teknologier - da al teknologi forandres, når den møder praksis:

Forudsigelserne af analytisk uniformitet (Marcuse), af teknikkens sejr (Ellul) og af selv den rene verden af kalkulativ tænkning (Heidegger) er forkerte. Der vil inden for den nærmeste fremtid være diversitet, endda øget diversitet, inden for ensemblet af teknologier og deres flertydigheder (Ihde 1990:159).

Der er langt fra den Triple Helix-drevne innovations fantasier om robotter som Ava med en singularistisk kunstig intelligens og en tvetydig robot som SILBOT. Der er faktisk så langt, at det kun er vores egen menneskelige begrebsdannelse, der forbinder fantasi og maskine med det samme begreb „robot som Silbot“ og „robot som Ava“.

I Technucations danske studier af sociale robotter er værdien af robotten en kulturmarkør, der først og fremmest er et udefrakommende signal om det ønskværdige i en innovation, der lover velfungerende robotter i plejesektoren (Hasse 2013). Disse robotter, forestiller man sig, vil i fremtiden kunne gå og tale ligesom Ava, men i mødet med praksis bliver det klart, at robotter ikke kan klare sig uden massiv menneskelig opbakning. Det er personalets improvisationer, der får teknologiske innovationer til at blive brugbare innovationer i praksis. Selv om personalet kæmper med ukvalificerede sociale robotter, vil de forsøge at få dem til at give mening i de lokale institutionelle sammenhænge som skoler, plejehjem og hospitaler (Bruun et al. 2015; Hasse 2015; Leeson 2017). Disse institutionelle sammenhænge kan forstås som kulturøkologier (Hasse 2014), hvor teknologier har en agens som kroppe (se fx Bennett 2009) blandt andre kroppe, der kæmper for at finde en niche for deres fortsatte eksistens. Her ser det ud til, at sociale robotter hjælpes til en eksistens i kulturøkologier, fordi de, uanset deres udformning og funktion, opfattes som innovative af stærke ledere, og personalet strækker sig derfor for at inkludere dem.

Når velfærdsrobotter i vores forskning har en særstatus i forhold til at udfordre innovationsbegrebet forstået som ny værdi, er det, fordi de som Triple Helixdrevne innovationer ofte sælges (dyrt), på trods af at teknologien er ganske ufærdig og afhængig af en ofte ikke erkendt bearbejdelse gennem medarbejderdrevet 
innovation (Hasse \& Brandi 2012). At denne bearbejdelse finder sted, kræver en stor indsats fra de mennesker, der skal lære at omgås teknologierne. Derfor er „kilden til teknologisk innovation“ ikke bare den teknologiske fantasi, der driver visionsbårne innovationer, men i høj grad også den improviserede praksis, hvor robotterne implementeres. I modsætning til den store opmærksomhed, der er på sociale robotter i den kulturelle medieproduktion, er der meget lidt opmærksomhed på, hvorledes sociale robotter fungerer i praksis. Vores senkapitalistiske samfund tager sjældent den rytmiske praksisdrevne innovation i betragtning, når de sociale robotter anskaffes. Det er her, vi ser en hverdag udspille sig på helt andre måder end dem, som designerne af velfærdsrobotter som MERO og SILBOT forestiller sig ud fra en metronomisk Triple Helix-drevet innovation. Det kræver nytænkning at få robotter til at passe ind i etablerede praksisfællesskaber - og her er det ikke alene robotternes forudprogrammerede funktionalitet, der er innovativ, men også personalets anstrengelser.

Søgeord: sociale robotter, teknologi, innovation, kulturøkologi

\section{Noter}

1. Vores forskning er tilknyttet forskningsprogrammet „Fremtidsteknologi, kultur og læreprocesser" (http://edu.au.dk/forskning/omraader/fremtidsteknologi-kultur-og-laereprocesser/). Vi har i dette program haft en række projekter, der handler om teknologiforståelse, blandt andet projektet Technucation. Dette projekt byggede på midler fra Det Strategiske Forskningsråd og fokuserede i årene 2011-2015 på ansattes teknologiforståelse, når der bliver implementeret ny teknologi i uddannelses- og sundhedssektoren. Der indgik forskere fra Aarhus Universitet, Roskilde Universitet samt professionshøjskolerne UCC og Metropol.

2. Turing-testen er udviklet af den engelske datalog Alan M. Turing. Testen skal bruges til at afgøre, om maskiner bliver opfattet som intelligente væsener på et niveau, der svarer til menneskers. Testen afgør ikke, om maskiner kan tænke, men kun, om mennesker opfatter maskinens svar på lige fod med svar fra mennesker (Turing 1950).

3. En kulturmarkør er en særligt „friktioneret“ materialitet, der i en analyse af kulturøkologier peger mod „et forgrenet netværk af relaterede betydninger, der kan inkludere og ekskludere såvel betydninger som fysiske manifestationer af ord, genstandsartefakter, handlinger og mennesker" (Hasse 2011:149).

4. Triple Helix-modellen blev udviklet i slutningen af 1990'erne af Henry Etzkowitz og Loet Leydesdorff (2000) som et forsøg på bedre at forstå de udviklingsprocesser, der er blevet observeret mellem institutioner og innovativ udvikling i samfundet. Modellen viser, at tre relevante områder - industrien, den akademiske verden og den offentlige sektor - er sammenvævede, og at hver af disse områder samtidig følger en særlige dagsorden af henholdsvis kapitalfrembringelse, nye ideer og offentlig kontrol. Det er i dette dynamiske samspil mellem særinteresser og sammenvævninger, at Triple Helix-modellen er i bevægelse og konstant forandrer (magt) relationer i samfundet (se også Salamon, Lex \& Friberg 2016). 


\section{Litteratur}

Alac, Morana

2009 Moving Android: On Social Robots and Body-in-Interaction. Social Studies of Science 39(4):491-528.

Amabile, Teresa M.

1988 A Model of Creativity and Innovation in Organizations. In: B.M. Staw \& L.L. Cummings (eds): Research in Organizational Behaviour 10:123-67.

Balsamo, Anne

2011 Designing Culture: The Technological Imagination at Work. Durham, NC: Duke University Press.

Bennett, Jane

2009 Vibrant Matter: A Political Ecology of Things. Durham, NC: Duke University Press.

Breazeal, Cynthia L.

2002 Designing Sociable Robots. Cambridge, MA: The MIT Press.

Bruner, Edward

1993 Epilogue: Creative Persona and the Problem of Authenticity. In: S. Lavie, K. Narayan \& R. Rosaldo (eds): Creativity/Anthropology. Ithaca: Cornell University Press.

Bruun, Maja Hojer, Cathrine Hasse \& Signe Hanghøj

2015 Studying Social Robots in Practiced Places. Techne: Research in Philosophy and Technology, vol. 19 no. 2:143-65.

Chang, Wan-Ling \& Selma Šabanović

2014 Observational Study of Naturalistic Interactions with the Socially Assistive Robot PARO in a Nursing Home. Robot and Human Interactive Communication, ROMAN: The 23rd IEEE International Symposium: 294-99.

Darsø, Lotte

2013 Innovationspædagogik. Kunsten at fremelske innovationskompetence. København: Samfundslitteratur.

Esbensen, Gertrud L.

2016 Robotter i Folkeskolen (normalklasser). Begrundelser, visioner, faktisk brug og udfordringer. Faglig rapport fra Danmarks Institut for Pædagogik og Uddannelse. http://edu.au.dk/fileadmin/edu/Fremtidsteknologi/E-bog_Robotter_i folkeskolen.pdf. Besøgt 17. marts 2017.

Etzkowitz, Henry \& Loit Leydesdorff

2000 The Dynamics of Innovation: From National Systems and 'Mode 2' to a Triple Helix of University-Industry-Government Relations. Research Policy 29(2):10923.

Fox, Stephen

2000 Communities of Practice, Foucault and Actor-Network Theory. Journal of Management Studies 37(6):853-67.

Frey, Carl B. \& Michael A. Osborne

2013 The Future of Employment: How Susceptible are Jobs to Computerisation? OMS Working Papers, September 18. doi:http://www.futuretech.ox.ac.uk/sites/ futuretech.ox.ac.uk/files/The Future of Employment OMS Working Paper 0.pdf. Besøgt 19. september 2015. 
Harkins, Arthur, John Tomsyck \& George Kubik

2002 Prospective Education for an Innovation Economy. On the Horizon 10(1):17-22.

Hasse, Cathrine

2011 Kulturanalyse i organisationer. København: Samfundslitteratur.

2013 Artefacts that Talk: Mediating Technology as Multistable Signs and Tools. Subjectivity 6 (1):79-100.

2014 An Anthropology of Learning. On Nested Frictions in Cultural Ecologies. Doordrecht: Springer Verlag.

2015 Multistable Roboethics. In: K.B.O. Friis \& R.P. Crease (eds.): Technoscience and Postphenomenology. The Manhattan Papers. Pp. 169-88. London: Lexington Books.

Hasse, Cathrine \& Ulrik Brandi

2012 Employee Driven Innovation: From Spontaneous Idea Generation to New Collective Practices. In: S. Høyrup, C. Hasse, K. Møller, M. Horst \& M.

Bonnafous (eds): Employee-driven Innovation. Pp. 127-49. New York: Macmillan Publishers Limited.

Hasse, Cathrine \& Lene S. Brok (red.)

2015 TEKU-modellen. Teknologiforståelse i professionerne. København: Forlaget U Press.

Ihde, Don

1990 Technology and the Lifeworld. From Garden to Earth. Bloomington: Indiana University Press.

Ingold, Tim

2007 Materials against Materiality. Archaeological Dialogues 14(1):1-16.

Ingold, Tim \& Elizabeth Hallam (eds)

2007 Creativity and Cultural Improvisation: An Introduction. In: T. Ingold \& E. Hallam: Creativity and Cultural Improvisation. Pp. 1-24. Oxford: Berg.

Kurzweil, Ray

2005 The Singularity is Near: When Humans Transcend Biology. New York: Viking Books.

Law, John \& John Hassard (eds)

1999 Actor Network Theory and After. Oxford: Blackwell Publishers.

Leeson, Christina

2017 Anthropomorphic Robots on the Move. Ph.d.-afhandling. København: Institut for Antropologi, Københavns Universitet.

MTVU

2006 Teknologisk fremsyn om kognition og robotter. København: Ministeriet for Videnskab, Teknologi og Udvikling.

Ritzer, George

1996 McDonaldiseringen af samfundet. København: Hans Reitzels Forlag.

Salamon, Karen Lisa, Simon Lex \& Torbjørn Friberg

2016 På tværs af velfærdsstaten: Pligten til forandring via konvergens. Tidsskriftet Antropologi 73:119-38. 
Schumpeter, Joseph

1942 Capitalism, Socialism and Democracy. New York: Harper.

Steward, Julian H.

1972 Theory of Culture Change: The Methodology of Multilinear Evolution. Illinois: University of Illinois Press.

Søndergaard, Katia D. \& Cathrine Hasse (red.)

2012

Teknologiforståelse på skoler og hospitaler. Aarhus: Aarhus Universitetsforlag.

Turing, Alan M.

$1950 \quad$ Computing Machinery and Intelligence. Mind 49:433-60. 